\title{
Identification and classification of Lactobacillus acidophilus, L. gasseri and $L$. johnsonii strains by SDS-PAGE and rRNA-targeted oligonucleotide probe hybridization
}

\author{
Bruno Pot, ${ }^{1 *}$ Christian Hertel, ${ }^{2}$ Wolfgang Ludwig, ${ }^{2}$ Patrick Descheemaeker, ${ }^{1}$ \\ KaREL Kersters ${ }^{1}$ and Karl-HeInZ SchleIFER ${ }^{2}$ \\ ${ }^{1}$ Laboratorium voor Microbiologie, Universiteit Gent, K. L. Ledeganckstraat 35, B-9000 Gent, Belgium \\ ${ }^{2}$ Lehrstuhl für Mikrobiologie, Technische Universität München, Arcisstrasse 21, D-8000 München 2, Germany
}

(Received 6 August 1992; revised 12 November 1992; accepted 17 November 1992)

\begin{abstract}
Thirty-two strains originally identified as Lactobacillus acidophilus and $L$. gasseri were screened for their taxonomic homogeneity by SDS-PAGE of whole-cell proteins. After numerical comparison of the resulting protein electrophoretic fingerprints, two well-delineated clusters were detected. The majority of the strains grouped in one electrophoretic cluster, which contained the type strain of $L$. acidophilus and corresponds to DNA group A1 of Johnson, J. L., Phelps, C. F., Cummins, C. S., London, J. \& Gasser, F. (1980; International Journal of Systematic Bacteriology 30, 53-68). Another cluster corresponded to DNA group B. It contained two subclusters, which agreed perfectly with DNA subgroups B1 ( $L$. gasseri) and B2 (L. johnsonii), respectively. The 23S rRNA genes were partially sequenced and 23S-rRNA-targeted oligonucleotide probes were designed for identification of DNA groups A1, B1 and B2. Probe Lbg reacted with all strains of electrophoretic cluster B1 (L. gasseri), probe Lbj hybridized with strains of cluster B2 (L. johnsonii) and probe Lba with strains of cluster A1 (authentic $L$. acidophilus). The probes were successfully used for the identification of strains belonging to the respective species. The phylogenetic relationship of a representative of $L$. johnsonii was determined by comparative sequence analysis of the $16 \mathrm{~S}$ rRNA genes. It is very closely related to $L$. gasseri.
\end{abstract}

\section{Introduction}

Identification of bacteria is essential in both basic and applied research. The identification of lactic acid bacteria (LAB) depends mainly on physiological and biochemical criteria. These procedures are not only time-consuming, but owing to an increasing number of LAB species, are also very ambiguous. rRNA sequencing and DNA:DNA hybridization studies have improved our taxonomic knowledge on the generic and suprageneric relationships of LAB (Collins et al., 1989, 1991; KilpperBälz et al., 1982; Ludwig et al., 1985; Martinez-Murcia \& Collins, 1990; Schleifer et al., 1985; Schleifer, 1987; Schleifer \& Kilpper-Bälz, 1987). Identification to the species level, however, is still time-consuming, requires the back-up of a large database of rRNA sequences and

\footnotetext{
*Author for correspondence. Tel. 91 645114; fax 91 645346; e-mail gels@lmgmicro.rug.ac.be.
}

Abbreviation: LAB, Lactic acid bacteria. for very closely related species even rRNA sequence analysis may not be sufficient. In this study, we have applied the complementary use of two molecular screening methods to the improved classification and identification of the industrially important but heterogeneous species Lactobacillus acidophilus (Moro, 1900; Holland, 1920). L. acidophilus is believed to play an important role in human health and nutrition by its influence on the intestinal flora (Hawley et al., 1959; Fiedler \& Kandler, 1964; Mitsuoka, 1969; Mitsuoka et al., 1969; Reuter, 1969). Despite considerable industrial and medical interest, the systematics of this species remained confusing for a long time (Moro, 1900; OrlaJensen et al., 1936; Hansen \& Mocquot, 1970), and a considerable serological heterogeneity has been shown (Sharpe, 1970; Gasser, 1970). The heterogeneity was also reflected by the results of DNA:DNA hybridization studies (Johnson et al., 1980; Lauer et al., 1980). L. acidophilus and $L$. gasseri are found in similar habitats and cannot be distinguished by simple phenotypic criteria (Kandler \& Weiss, 1986). More recently, the species L. gallinarum and $L$. johnsonii were created for the 
Table 1. List of strains used

Homologous strain numbers (replicates) are indicated. The Table lists the results of the cluster analysis of the SDS-PAGE patterns of whole-cell proteins, and the $23 \mathrm{~S}$ rRNA-targeted oligonucleotide probe reactions with probes specific for strains of $L$. acidophilus, $L$. gasseri and $L$. johnsonii.

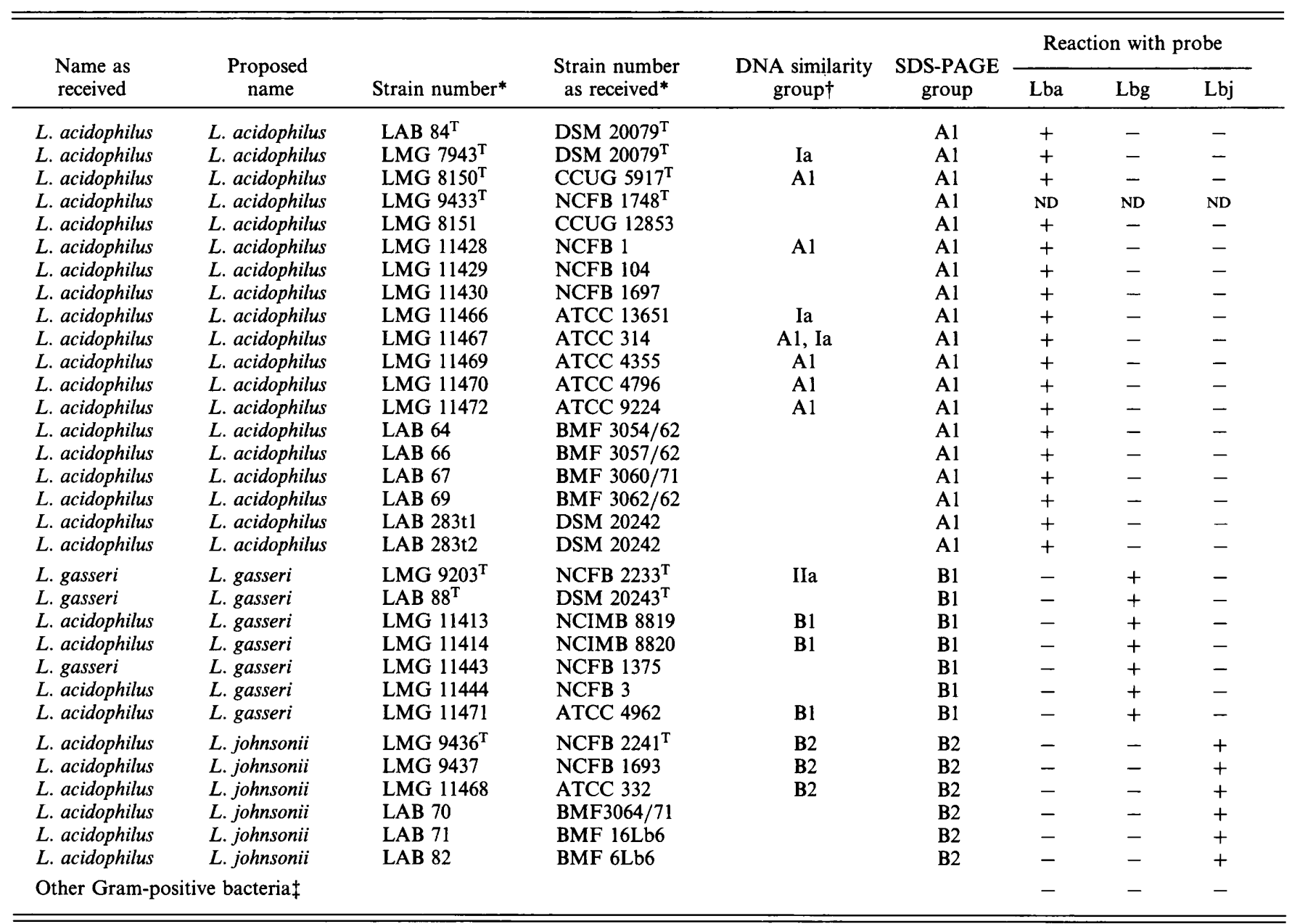

ND, Not determined.

*ATCC, American Type Culture Collection, Rockville, MD, USA; BMF, Bundesanstalt für Milchforschung, Kiel, Germany; CCUG, Culture Collection of the Department of Clinical Bacteriology, University of Göteborg, Göteborg, Sweden; DSM, Deutsche Sammlung von Microorganismen, Braunschweig, Germany; LAB, Lactic Acid Bacteria Culture Collection, Laboratorium voor Microbiologie, Universiteit Gent, Gent, Belgium; LMG, Culture Collection of the Laboratorium voor Microbiologie, Universiteit Gent, Gent, Belgium; NCFB, National Collection of Food Bacteria, Reading, UK; NCIMB: National Collection of Industrial and Marine Bacteria, Aberdeen, UK.

$\dagger$ Ia and IIa refer to DNA groups described by Lauer et al. (1980); other indications refer to Johnson et al. (1980).

$\ddagger$ Bacillus cereus, B. licheniformis, B. subtilis, Enterococcus faecalis, E. faecium, L. alimentarius, L. amylovorus (L. acidophilus DNA group A3), L. brevis, L. buchneri, L. casei subsp. casei, L. casei subsp. rhamnosus, L. casei subsp. pseudoplantarum, L. delbrueckii subsp. bulgaricus, L. crispatus (L. acidophilus DNA group A2), L. delbrueckii subsp. delbrueckii, L. delbrueckii subsp. lactis, L. fermentum, L. gallinarum (L. acidophilus DNA group A4), L. helveticus, L. kefir, L. plantarum, L. plantarum subsp. arabinosus, Lactococcus lactis subsp. cremoris, Lc. lactis subsp. lactis, Leuconostoc lactis, Le. mesenteroides, Le. mesenteroides subsp. cremoris, Streptococcus thermophilus.

L. acidophilus DNA similarity groups A4 and B2, respectively (Fujisawa et al., 1992).

In this paper, we have applied SDS-PAGE, rRNA sequence analysis and oligonucleotide probe hybridization to study the relationships in the heterogeneous L. acidophilus complex. Highly standardized SDS-PAGE of whole-cell proteins allows fast screening of large numbers of strains for comparative purposes. Recent data in the literature support the overall correlation between the results of numerical analysis of protein patterns and DNA:DNA hybridization studies (Costas et al., 1990; Dijkshoorn et al., 1990; Pot et al., 1992; Vauterin et al., 1990; Vandamme et al., 1991). SDSPAGE can only be used on a relatively large number of cells, derived from a pure culture, whereas rRNAtargeted oligonucleotide probe hybridization is a fast alternative for identification of relatively small numbers of cells or strains from pure and mixed cultures present in complex nutritional environments (e.g. milk). Nucleic acid probes are known to be especially useful for rapid 
Table 2. Sequences, specificities, and hybridization and washing temperatures of the oligonucleotide probes

\begin{tabular}{|c|c|c|c|c|c|}
\hline \multirow[b]{2}{*}{ Probe } & \multirow[b]{2}{*}{ Sequence } & \multirow[b]{2}{*}{ Specificity* } & \multirow[b]{2}{*}{ Target $\dagger$} & \multicolumn{2}{|c|}{ Temperature $\left({ }^{\circ} \mathrm{C}\right)$ for: } \\
\hline & & & & Hybridization & Washing \\
\hline Lba & $5^{\prime}$ TCTTTCGATGCATCCACA $3^{\prime}$ & L. acidophilus (cluster A1) & $1159-1180$ & 40 & 49 \\
\hline Lbg & $5^{\prime}$ TCCTTTGATATGCATCCA $3^{\prime}$ & L. gasseri (cluster B1) & $1160-1178$ & 40 & 50 \\
\hline Lbj & $5^{\prime}$ ATAATATATGCATCCACAG $3^{\prime}$ & L. johnsonii (cluster B2) & $1158-1179$ & 40 & 49 \\
\hline
\end{tabular}

* The cluster indication refers both to the electrophoretic clusters obtained in this paper and to the DNA groups as revealed by DNA similarity studies (Johnson et al., 1980).

$\dagger$ The numbers indicate homologous positions of the E. coli 23S rRNA (Brosius et al., 1981).

detection and identification of bacteria and have been used successfully in food products (Schleifer, 1990).

\section{Methods}

Strains used. The bacterial strains examined are listed in Table 1. A number of strains were analysed which have been included previously in the DNA hybridization studies of Johnson et al. (1980) and Lauer $e t$ al. (1980). In addition, strains studied were either derived from culture collections or isolated in the framework of the Biotechnology Research for Innovation, Development and Growth in Europe (BRIDGE) Tproject on Lactic Acid Bacteria of the Commission of the European Communities.

Maintenance of cultures. Cultures were maintained by weekly transfer in MRS broth (De Man et al., 1960; Oxoid). Cells were incubated in closed screw-capped tubes for $24 \mathrm{~h}$ at $30^{\circ} \mathrm{C}$ after which they were transferred to room temperature. Purity was checked by plating on MRS agar (Oxoid).

PAGE of proteins. All strains were grown on MRS agar in Roux flasks at $30^{\circ} \mathrm{C}$ for $24 \mathrm{~h}$. Roux flasks were inoculated from a $24 \mathrm{~h} 10 \mathrm{ml}$ MRS broth culture. Whole-cell protein extracts were prepared as described previously (Kiredjian et al., 1986). Registration of the protein electrophoretic patterns, normalization of the densitometric traces, grouping of strains by the Pearson product moment correlation coefficient $(r)$ and UPGMA cluster analysis were performed by the techniques described by Pot et al. (1993) using the software package GELCOMPAR (Version 1.4; L. Vauterin \& P. Vauterin, unpublished).

Extraction and purification of DNA. DNA was isolated from lactobacilli according to the method of Lewington et al. (1987) with some modifications. Stationary phase culture $(1 \mathrm{ml})$ was harvested and resuspended in $100 \mu \mathrm{l}$ of $50 \mathrm{~mm}$-Tris $/ \mathrm{HCl}, 50 \mathrm{~mm}$-sodium chloride, $10 \mathrm{~mm}$-EDTA, $\mathrm{pH} 8$. Fifteen microlitres of lysozyme $\left(10 \mathrm{mg} \mathrm{m}^{-1}\right)$ and of mutanolysin $\left(5000 \mathrm{U} \mathrm{ml}^{-1}\right)$ were added and incubated at $37^{\circ} \mathrm{C}$ for $15 \mathrm{~min}$. Forty microlitres of $25 \%$ (w/v) SDS were then added, heated to $65^{\circ} \mathrm{C}$ for $5 \mathrm{~min}$ and the mixture was vortexed vigorously for $5 \mathrm{~s}$. Then $33 \mu \mathrm{l}$ of $5 \mathrm{M}$-sodium chloride were added, mixed and left on ice for $1 \mathrm{~h}$. After centrifugation for $15 \mathrm{~min}$, the supernatant fluid was treated once with chloroform-isoamyl alcohol $(24: 1, \mathrm{v} / \mathrm{v})$. DNA was precipitated with ethanol and resuspended in TE buffer $(10 \mathrm{mM}-\mathrm{Tris} / \mathrm{HCl}$, 1 mM-EDTA, $\mathrm{pH}$ 8). RNAase A was added to a final concentration of $10 \mu \mathrm{g} \mathrm{ml}^{-1}$ and then incubated at $37^{\circ} \mathrm{C}$ for $30 \mathrm{~min}$.

Designing of probes. Variable regions, homologous to positions 457-1703 of the 23S rRNA genes of Escherichia coli (Brosius et al., 1981), were amplified from the bulk DNA by PCR (Saiki et al., 1988) in combination with gene-specific primers (5' AGTACCGYGAGGGAAAG $3^{\prime}$ and 5' CCTTCTCCCGAAGTTACGG 3'). The amplified fragments were purified applying the GeneClean kit (Bio 101) and sequenced directly using the T7-sequencing-kit (Pharmacia). Comparative analysis of the $23 \mathrm{~S}$ rRNA gene fragment sequences revealed regions that could be used as specific target sites for DNA probes (Table 2). Oligonucleotides complementary to the 23S rRNA were obtained from MWG Biotech (Ebersberg, Germany).

Dot blot hybridization. Labelling of the probes, nucleic acid extractions, and dot blot hybridizations were performed as described previously by Hertel et al. (1991).

$16 S r R N A$ sequence analysis. In vitro amplification and sequencing of 16S rRNA genes was performed as described by Weizenegger et al. (1991).

\section{Results and Discussion}

The results of the numerical analysis of the SDS-PAGE protein patterns confirmed the heterogeneity of $L$. acidophilus. Fig. 1 shows the clusters formed after numerical analysis of the total protein profile [points 10 320 of the 400 points registered, omitting the stacking gel/separation gel interface (positions $0-9$ ) and the front of the electrophoretic protein profile (positions 321400)]. SDS-PAGE clearly discriminated between the two DNA similarity groups A and B of Johnson et al. (1980) (correlation level $r=0 \cdot 60$ ). The first cluster, homologous to DNA group A1, and therefore labelled cluster A1 (Fig. 1), comprised the majority of the strains, including the type strain of L. acidophilus, for which three independently obtained subcultures (Table 1) were investigated (mean correlation $r=0.94$; Fig. 1). Cluster Al is delineated at a correlation level of $r=0.88$, and could clearly be differentiated from the other subgroups of DNA group A (results not shown). The second cluster, homologous to DNA similarity group $B$, is composed of two subclusters (B1 and B2; Fig. 1), similar to the two DNA subgroups B1 and B2 as defined by Johnson et al. (1980). Strains of L. acidophilus DNA subgroups B1 (Johnson et al., 1980) and IIa (Lauer et al., $1980)$ are believed to be synonymous with $L$. gasseri (Lauer \& Kandler, 1980a,b; Lauer et al., 1980). We included two different subcultures of the type strain of $L$. gasseri (Table 1) and found them both to belong to the subcluster B1 (mean correlation $r=0.96$; Fig. 1). 


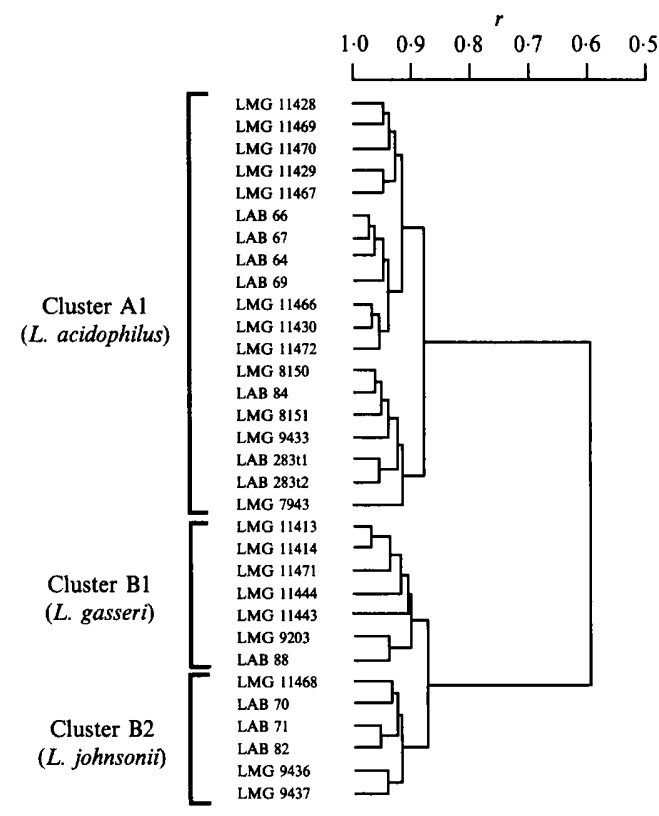

Fig. 1. The mean correlation coefficient $(r)$, represented as a dendrogram calculated by the unweighted average pair grouping method, for all strains investigated. The points $10-320$ of the 400 point traces were used for the calculation of similarities between individual pairs of traces.

DNA similarity group B2 was recently named $L$. johnsonii (Fujisawa et al., 1992). The proposed type strain (ATCC 33200) was identical to strain LMG $9436^{\mathrm{T}}$, which was obtained from the National Collection of Food Bacteria (Reading, UK) as NCFB $2241^{\mathrm{T}}$. From Fig. 1 it is evident that $L$. johnsonii BMF 6Lb6 (LAB 82) is closely related to L. johnsonii ATCC 332 (LMG 11468) studied by Fujisawa et al. (1992). The phylogenetic affiliation of strain BMF 6Lb6 was determined by comparative sequence analysis of its 16S rRNA genes. (EMBL accession number M99704). When compared to the 16S rRNA sequence of $L$. gasseri (Ribosomal RNA Data Base Project, RDP; Olson et al., 1991) a similarity of $99.4 \%$ was found, confirming the very close relationship of $L$. johnsonii and $L$. gasseri.

Partial sequence analysis of 23S rRNA genes of $L$. acidophilus DSM $20079^{\mathrm{T}}, L$. johnsonii LMG $9436^{\mathrm{T}}, L$. johnsonii $\mathrm{BMF} 6 \mathrm{Lb6}, L$. gasseri LMG $9203^{\mathrm{T}}$ and $L$. gasseri LMG 11444 was carried out. Sequence differences were detected within highly variable regions of the genes, which could be used for the design of rRNA-targeted specific oligonucleotide probes. The sequence of the probes, the hybridization and washing temperatures, as well as the target sites are summarized in Table 2 . The specificities of the probes are given in Table 1 . Probe Lba hybridized exclusively to target nucleic acids of all strains assigned to electrophoretic cluster A1 in the present study. Probe Lbg was proven to be specific for the strains belonging to electrophoretic subcluster B1 (L. gasseri), and probe $L b j$ reacted only with nucleic acids from representatives of electrophoretic cluster B2 (L. johnsonii).

The prescreening of $L$. acidophilus-like strains at a fine taxonomide level by SDS-PAGE of whole-cell proteins has facilitated the subsequent design of three $23 \mathrm{~S}$ rRNAbased oligonucleotide probes for identification. These probes can be used with a high degree of confidence, and we consider them to be one of the fastest ways for identification of specific LAB species in applied and fundamental research.

The 16S rRNA sequence analysis and the comparison of the whole-cell protein electrophoretic patterns showed that $L$. johnsonii is very closely related to $L$. gasseri.

We thank Mr D. Dewettinck for excellent technical assistance. This research was carried out in the framework of contract BIOTCT91-0263 of the Biotechnology BRIDGE T-project on Lactic Acid Bacteria of the Commission of the European Communities.

\section{References}

Brosius, J., Dull, J. J., Sleater, D. D. \& Noller, H. F. (1981). Gene organization and primary structure of a ribosomal RNA operon from Escherichia coli. Journal of Molecular Biology 148, 107-127.

Collins, M. D., Ash, C., Farrow, J. A. E., Wallbanks, S. \& Williams, A. M. (1989). 16S ribosomal ribonucleic acid sequence analyses of lactococci and related taxa. Description of Vagococcus fluvialis gen. nov., sp. nov. Journal of Applied Bacteriology 67, 453-460.

Collins, M. D., Rodrigues, U., Ash, C., Aguirre, M., Farrow, J. A. E., Martinez-Murcia, A. Phillips, B. A., Williams, A. M. \& Wallbanks, S. (1991). Phylogenetic analysis of the genus Lactobacillus and related lactic acid bacteria as determined by reverse transcriptase sequencing of 16S rRNA. FEMS Microbiology Letters 77, 5-12.

Costas, M., Pot, B., Vandamme, P., Kersters, K., Owen, R. J. \& Hill, L. R. (1990). Inter-laboratory comparative study of the numerical analysis of one-dimensional sodium dodecyl sulphate-polyacrylamide gel electrophoretic protein patterns of Campylobacter strains. Electrophoresis 11, 467-474.

Dijkshoorn, L., Tuernberg, I., Pot, B., Michel, M. F., Ursing, J. \& KERSTERS, K. (1990). Numerical analysis of cell envelope protein profiles of Acinetobacter strains classified by DNA-DNA hybridization. Systematic and Applied Microbiology 13, 338-344.

FiedleR, F. \& KandleR, O. (1964). Die Konstanz der Artmerkmale von L. acidophilus bei Fortzüchtung in Milch. Milchwissenschaft 19, 465-473.

Fujisawa, T., Benno, Y., Yaeshima, T. \& Mitsuoka, T. (1992). Taxonomic study of the Lactobacillus acidophilus group, with recognition of Lactobacillus gallinarum sp. nov. and Lactobacillus johnsonii sp. nov. and synonymy of Lactobacillus acidophilus group A3 (Johnson et al., 1980) with the type strain of Lactobacillus amylovorus (Nakamura, 1981). International Journal of Systematic Bacteriology 32, 487-491.

GASSER, F. (1970). Electrophoretic characterization of lactic dehydrogenases in the genus Lactobacillus. Journal of General Microbiology 62, 223-239.

Hansen, P. A. \& Mocquot, G. (1970). Lactobacillus acidophilus (Moro) comb. nov. International Journal of Systematic Bacteriology 20, 325-327.

Hawley, H. B., Shepherd, P. A. \& Weather, D. M. (1959). Factors affecting the implantation of lactobacilli in the intestine. Journal of Applied Bacteriology 22, 360-367.

Hertel, C., Ludwig, W., Obst, M., Vogel, R. F., Hammes, W. P. \& 
SCHLEIFER, K. H. (1991). 23S rRNA-targeted oligonucleotide probes for the rapid identification of meat lactobacilli. Systematic and Applied Microbiology 14, 73-77.

Holland, D. F. (1920). Generic index of the commoner forms of bacteria. Journal of Bacteriology 5, 215-229.

Johnson, J. L., Phelps, C. F., Cummins, C. S., London, J. \& Gasser, F. (1980). Taxonomy of the Lactobacillus acidophilus group. International Journal of Systematic Bacteriology 30, 53-68.

KANDLER, O., \& WeISS, N. (1986). Genus Lactobacillus Beijerinck 1901 $212^{\mathrm{AL}}$. In Bergey's Manual of Systematic Bacteriology, vol. 2. pp. 1209-1234. Edited by P. E. Sneath, N. S. Mair \& M. E. Sharpe. Baltimore: Williams \& Wilkins.

KILPPER-BÄLZ, R., FisChER, G. \& SChleIFER, K. H. (1982). Nucleic acid hybridization of group $\mathrm{N}$ and group D streptococci. Current Microbiology 7, 245-250.

Kiredian, M., Holmes, B., Kersters, K., Guilvout, I. \& De Ley, J. (1986). Alcaligenes piechaudii, a new species from human clinical specimens and the environment. International Journal of Systematic Bacteriology 36, 282-287.

LAUER, E. \& KANDLER, O. (1980a). Lactobacillus gasseri sp. nov., a new species of the subgenus Thermobacterium. Zentralblatt für Bakteriologie Mikrobiologie und Hygiene I Abt. Originale C 1, 75-78.

LAUER, E. \& KANDLER, O. (1980 b). Validation of the publication of new names and new combinations previously effectively published outside the IJSB. List No. 4. International Journal of Systematic Bacteriology 30, 601

LAUER, E., Helming, C. \& KandLeR, O. (1980). Heterogeneity of the species Lactobacillus acidophilus (Moro) Hansen and Moquot as revealed by biochemical characteristics and DNA/DNA hybridisation. Zentralblatt für Bakteriologie Mikrobiologie und Hygiene I Abt. Originale C 1, 150-168.

Lewington, J., Greenaway, S. D. \& Spillane, B. J. (1987). Rapid small scale preparation of bacterial genomic DNA suitable for cloning and hybridization analysis. Letters in Applied Microbiology $5,51-53$.

Ludwig, W., Seewaldt, E., Kilpper-Bälz, R., Schleifer, K. H., Magrum, L., Woese, C. R., Fox, G. E. \& Stackebrandt, E. (1985). The phylogenetic position of Streptococcus and Enterococcus. Journal of General Microbiology 131, 543-551.

de Man, J. C., Rogosa, M. \& Sharpe, M. E. (1960). A medium for the cultivation of lactobacilli. Journal of Applied Bacteriology 23, 130-135.

Martinez-Murcia, A. J. \& Collins, M. D. (1990). A phylogenetic analysis of the genus Leuconostoc based on reverse transcriptase sequencing of 16S rRNA. FEMS Microbiology Letters 70, 73-84.

MrTsUOKA, T. (1969). Vergleichende Untersuchungen über die Laktobazillen aus den Faeces von Menschen, Schweinen, und Hühnern. Zentralblatt für Bakteriologie Parasitenkunde, Infektionskrankheiten und Hygiene I Abt. Originale C 210, 32-51.

Mitsuoka, T., KaneuChi, C., MoRishita, Y. \& Yamamoto, S. (1969).
Lactobacilli in the fermented-milk and acid-milk-drinks produced in Japan with special reference to the taxonomic problems. Japanese Journal of Bacteriology 24, 112-119.

MORO, E. (1900). Über den Bacillus acidophilus n. sp. Jahrbuch Kinderheilkunde 52, 38-55.

Olson, G. J., LARSEN, N. \& WoEse, C. R. (1991). The ribosomal RNA data base project (RDP). Nucleic Acids Research 19 (supplement), 2017-2021.

Orla-Jensen, S., Orla-Jensen, A. D. \& Winther, O. (1936). Bacterium bifidum und Thermobacterium intestinale. Zentralblatt für Bakteriologie Parasitenkunde, Infektionskrankheiten und Hygiene II Abt. 93, 321-343.

Pot, B., Vandamme, P. \& Kersters, K. (1993). Analysis of electrophoretic whole-organism protein fingerprints. In Chemical Methods in Bacterial Systematics (in the Press). Edited by $\mathbf{M}$. Goodfellow \& A. G. O'Donnell. Chichester: J. Wiley and Sons.

ReuTER, G. (1969). Zusammensetzung und Anwendung von Bakterienkulturen für therapeutische Zwecke. Arzneimittel-Forschung $19,103-109$.

Saiki, R. K., Gelfaud, D. H., Stoffel, S., Scharf, S. J., Higuchi, R., HoRN, G. T., Mullis, K. B. \& EHRlich, H. A. (1988). Primerdirected enzymatic amplification of DNA with a thermostab. DNA polymerase. Science $293,487-491$.

SCHLEIFER, K. H. (1987). Recent changes in the taxonomy of lactic acid bacteria. FEMS Microbiology Reviews 46, 201-203.

SCHLEIFER, K. H. (1990). DNA probes in food microbiology. Food Biotechnology 4, 585-598.

SCHLEIFER, K. H. \& KILPPER-BäLz, R. (1987). Molecular and chemotaxonomic approaches to the classification of streptococci, enterococci and lactococci: a review. Systematic and Applied Microbiology 10, 1-19.

Schleifer, K. H., Kraus, J., Dvorak, C., Kilpper-Bälz, R., Collins, M. D. \& FISCHER, W. (1985). Transfer of Streptococcus lactis and related streptococci to the genus Lactococcus gen. nov. Systematic and Applied Microbiology 6, 183-195.

SHARPE, M. E. (1970). Cell wall and cell membrane antigens used in the classification of lactobacilli. International Journal of Systematic Bacteriology 20, 509-518.

Vandamme, P., Pot, B. \& Kersters, K. (1991). Differentiation of campylobacters and Campylobacter-like organisms by numerical analysis of one-dimensional electrophoretic protein patterns. Systematic and Applied Microbiology 14, 57-66.

Vauterin, L., Vantomme, R., Pot, B., Hoste, B., Swings, J. \& KERSTERS, K. (1990). Taxonomic analysis of Xanthomonas campestris pv. begoniae and $X$. campestris pv. pelargonii by means of phytopathological, phenotypic, protein electrophoretic and DNA hybridization methods. Systematic and Applied Microbiology 13, $166-176$.

Weizenegger, M., Neumann, M., Stackebrandt, E., Weiss, N. \& LUDWIG, W. (1991). Eubacterium alactolyticum phylogenetically groups with Eubacterium limosum, Acetobacterium woodii and Clostridium barkeri. Systematic and Applied Microbiology 15, 32-36. 